\title{
Neurohormonal activation late after cavopulmonary connection
}

\author{
V E Hjortdal, E V Stenbøg, H B Ravn, K Emmertsen, K T Jensen, E B Pedersen, \\ K H Olsen, O K Hansen, K E Sørensen
}

\begin{abstract}
Objective-To determine whether patients with cavopulmonary connection have higher levels of vasoactive/water-salt regulating hormones and if so, whether hormone levels are related to postoperative haemodynamics and postoperative follow up.

Design-Cross sectional study.

Setting-University hospital.

Patients-20 patients (New York Heart Association functional class I-II), mean age 11 years (range 4 to 22 ), were studied at a mean of 2 years (0.5 to 6) after a total cavopulmonary connection (TCPC, $\mathrm{n}=12$ ) or a bidirectional Glenn anastomosis (BDG, $\mathrm{n}=8$ ).

Interventions-Cardiac catheterisation was performed and blood samples were drawn. Control blood samples were drawn from 33 healthy children, mean age 12 years (6 to 16).

Main outcome measures-Plasma levels of angiotensin II, renin, aldosterone, arginine, vasopressin, atrial natriuretic factor (ANF), brain natriuretic peptide (BNP).

Results-All neurohormones were significantly increased in both TCPC and BDG patients $(\mathrm{p}<0.05)$, with a fourfold increase in angiotensin II, renin, and aldosterone, and a twofold increase in vasopressin, $\mathrm{ANF}$, and BNP (compared with healthy controls). There was no correlation between haemodynamic variables and hormone levels. Angiotensin II and renin were inversely correlated with time to follow up. All subjects over 15 years $(n=5)$ had normal neurohormonal levels.

Conclusions-Neurohormones were raised for years after successful cavopulmonary operations but lower levels were observed with time on follow up. This supports the hypothesis that neurohormonal activation is primarily related to altered postoperative physiology and that adaptation takes place over time.

(Heart 2000;83:439-443)
\end{abstract}

Keywords: neurohormones; cavopulmonary connection; congenital heart disease; paediatric cardiology

Cavopulmonary operations are widely used for palliation of a variety of complex congenital heart defects. After a cavopulmonary connection, exercise tolerance remains significantly reduced. ${ }^{1-6}$ Multiple factors are likely to be involved in the exercise limitation, including abnormal pulmonary ventilation-perfusion ratio, ${ }^{7}$ increased pulmonary vascular resistance, ${ }^{7}$ reduced venous capacitance, ${ }^{8}$ and, not least, ventricular dysfunction. ${ }^{5}$

Neurohormonal activity has pathophysiological and therapeutic importance in adults with left ventricular dysfunction, ${ }^{9-12}$ and could also reflect ventricular dysfunction, predict prognosis, and serve as a guide to medical treatment after cavopulmonary operations. The levels of various neurohormones are known to be increased during the first few postoperative days after Fontan operations, ${ }^{13}$ but little is known about the late postoperative phase.

We measured plasma concentrations of angiotensin II, renin, aldosterone, arginine vasopressin (AVP), atrial natriuretic factor (ANF), and brain natriuretic peptide (BNP) at varying times after surgery in patients who had had cavopulmonary connection operations, and also in healthy control children, to determine whether patients had higher levels of vasoactive/water-salt regulating hormones and if so, whether hormone levels were related to postoperative haemodynamics and follow up.

\section{Methods}

PATIENTS

Between March 1995 and October 1997, 20 patients and 33 healthy children were enrolled in the study. Patients had undergone either a total cavopulmonary connection (TCPC) or a bidirectional Glenn (BDG) operation. There were eight girls and 12 boys. The median age at follow up was 11 years (range 4 to 22), and the median time after operation was two years (range 0.5 to 6). Details of the cardiac anatomy, age at final operation, previous palliation, and type of final procedure are summarised in table 1 .

Nine patients had an intra-atrial tunnel TCPC, with a fenestration in four. Eleven patients had a BDG. Three had interrupted inferior vena cava with azygos drainage to the superior vena cava. One BDG patient had no additional source of pulmonary flow, two had modified Blalock-Taussig shunts, while five had preserved antegrade flow through an obstructed (native or banded) pulmonary artery.

Four patients (three TCPC, one BDG) were on coumarins, one (TCPC) on diuretics, and one (TCPC) on a $\beta$ blocker. 
Table 1 Patient characteristics

\begin{tabular}{|c|c|c|c|c|c|c|}
\hline No & Diagnoses & Age at surgery (years) & Banding & Shunt & Operation & Fenestration \\
\hline 1 & TA, TGA, PS & 6 & & & ТCPC & \\
\hline 2 & $\mathrm{TA}$ & 6 & & 1 & ТСPC & \\
\hline 3 & $\mathrm{TA}$ & 13 & 1 & & TCPC & \\
\hline 4 & TA, TGA & 4 & & 1 & TCPC & Yes \\
\hline 5 & MA, DORV, PS & 7 & & & ТСРC & \\
\hline 6 & TA & 3 & & 1 & TCPC & Yes \\
\hline 7 & $\mathrm{TA}$ & 3 & 2 & & TCPC & Yes \\
\hline 8 & DILV, PS & 4 & & 2 & TCPC & \\
\hline 9 & DILV & 4 & 1 & & TCPC & Yes \\
\hline 10 & TA, PS, LAI & 21 & & & TCPC (IIVC) & \\
\hline 11 & MA, DORV, PS, LAI & 10 & & & TCPC (IIVC) & \\
\hline 12 & DILV, TGA, PS, LAI & 6 & & 2 & TCPC (IIVC) & \\
\hline 13 & DILV, TGA & 15 & 1 & & BDG & \\
\hline 14 & DILV, TGA & 6 & 1 & & $\mathrm{BDG}$ & \\
\hline 15 & DILV, TGA, PS & 10 & & & BDG & \\
\hline 16 & DILV, PS & 12 & & & BDG & \\
\hline 17 & TA, PA & 6 & & $1^{\star}$ & BDG & \\
\hline 18 & TA, PA & 10 & & $3 \dagger$ & BDG & \\
\hline 19 & $\mathrm{TA}$ & 8 & & $2^{\star}$ & BDG & \\
\hline 20 & TA, TGA, PS & 18 & & & BDG & \\
\hline
\end{tabular}

*One, †two Blalock-Taussig shunt(s) closed at or before surgery.

BDG, bidirectional Glenn; DILV, double inlet left ventricle; DORV, double outlet right ventricle; IIVC, interrupted inferior vena cava; LAI, left atrial isomerism; MA, mitral atresia; PA, pulmonary atresia; PS, pulmonary stenosis; TA, tricuspid atresia; TCPC, total cavopulmonary connection; TGA, transposition of the great arteries.

Control blood samples were obtained from 33 healthy children, 16 girls and 17 boys, with a median age of 12 years (range 6 to 16 ).

Informed consent was obtained from each patient or parent and the study was approved by the regional ethics committee.

\section{CARDIAC CATHETERISATION}

At follow up, all patients underwent complete right and left heart catheterisation. Six patients were investigated under local anaesthesia while the remaining patients received ketamine, propofol, and atropine. Pressures were measured using fluid filled catheters. Angiography was performed to assess the venous pathways and possible collaterals, and to estimate systolic ventricular function. Systemic ventricular function was assessed subjectively from the angiograms by an observer blinded to the neurohormonal results and arbitrarily defined as normal (ejection fraction $>60 \%$ ), mildly reduced (ejection fraction 50-60\%), and moderately reduced (ejection fraction $<50 \%$ ). Systemic and pulmonary blood flows were estimated using the Fick principle.

BLOOD SAMPLES

During catheterisation, blood samples were withdrawn through the catheter. Plasma was separated and stored at $-80^{\circ} \mathrm{C}$ before assay of angiotensin II, renin, aldosterone, AVP, ANF, and BNP. Blood samples were also analysed for packed cell volume, creatinine, urea, sodium, potassium, and albumin. Control blood samples were obtained from the 33 healthy fasting unsedated children. Blood samples were drawn from a peripheral arm vein and processed as described below.

NEUROHORMONE ANALYSIS

Angiotensin II was determined by a modified radioimmunoassay (RIA) method. ${ }^{14}$ Detection level was $2 \mathrm{pmol} / 1$. The intra-assay and interassay coefficients of variation were $8 \%$ and $12 \%$.

Renin was measured by a commercial RIA kit (Amersham International, UK and Nichols
Institute, Switzerland). The intra-assay and interassay coefficients of variation were $2.5 \%$ and $7.4 \%$.

Aldosterone was measured by a modified RIA method. ${ }^{15}$ The lower detection limit was $42 \mathrm{pmol} / 1$. The intra-assay and interassay coefficients of variation were $9 \%$ and $13 \%$.

AVP was measured by RIA as previously described. ${ }^{16}$ The lower detection limit was 0.5 $\mathrm{pmol} / 1$. The intra-assay variation was $9 \%$ and the interassay variation $13 \%$.

ANF was determined by RIA. ${ }^{17}$ The minimum detection limit was $0.5 \mathrm{pmol} / 1$ plasma, and the intra-assay and interassay coefficients of variation were $10 \%$ and $12 \%$.

BNP was determined by RIA. ${ }^{18}$ The intraassay and interassay coefficients of variation were $8.0 \%$ and $12.9 \%$ for a sample pool with a mean BNP concentration of $1.2 \mathrm{pmol} / 1$. The corresponding values for a sample pool with a mean BNP concentration of $6.4 \mathrm{pmol} / 1$ were $3.7 \%$ and $8.4 \%$. The detection limit was 0.6 $\mathrm{pmol} / \mathrm{l}$. There was no cross reactivity between $\mathrm{ANF}$ and BNP.

\section{STATISTICS}

Descriptive data are expressed as median values (interquartile range) as some variables were distributed asymmetrically. Comparison of plasma levels of neurohormones was carried out with the TCPC and BDG patients separately and with all patients pooled against the control group. Comparisons between the two groups and the controls were done using unpaired rank sum test (Mann-Whitney). The determinants of plasma levels of neurohormones were then assessed by multiple linear regression analysis, with plasma levels of neurohormones as the dependent variable and haemodynamic variables-such as systemic and pulmonary blood pressures, systemic and pulmonary saturation, systemic (Qs) and pulmonary blood flow (Qp), and ventricular ejection fraction-and follow up time as independent variables. Both actual and indexed values of blood flows were analysed. Analyses were performed both on raw data and 
Table 2 Haemodynamic characteristics

\begin{tabular}{|c|c|c|c|}
\hline & $T C P C(n=12)$ & $B D G(n=8)$ & \\
\hline Systolic arterial pressure (mm Hg) & $97(80$ to 110$)$ & $93(87$ to 100$)$ & \\
\hline Diastolic arterial pressure $(\mathrm{mm} \mathrm{Hg})$ & $55(55$ to 64$)$ & $60(57$ to 69$)$ & \\
\hline Mean pulmonary artery pressure $(\mathrm{mm} \mathrm{Hg})$ & $8(7$ to 10$)$ & $9(8$ to 11$)$ & \\
\hline Central venous pressure $(\mathrm{mm} \mathrm{Hg})$ & $9(8$ to 12$)$ & $11(9$ to 13$)$ & \\
\hline Gradient over anastomoses $(\mathrm{mm} \mathrm{Hg})$ & $0(0$ to 1.5$)$ & $0(0$ to 1.0$)$ & \\
\hline $\mathrm{EDP}(\mathrm{mm} \mathrm{Hg})$ & $6(3$ to 8$)$ & $6(5$ to 6$)$ & \\
\hline Systemic arterial saturation (\%) & 96 (92 to 99$)$ & $90(89$ to 92$)$ & * \\
\hline Mixed venous saturation (\%) & $75(74$ to 81$)$ & $77(74$ to 81$)$ & \\
\hline Pulmonary arterial saturation (\%) & 75 (70 to 83$)$ & 88 (78 to 92$)$ & $\mathrm{p}=0.07$ \\
\hline Qs $(1 / \mathrm{min})$ & $3.9(3.6$ to 6.2$)$ & $4.4(2.6$ to 5.8$)$ & \\
\hline $\mathrm{Qp}(1 / \mathrm{min})$ & $3.9(3.2$ to 5.3$)$ & $5.7(4.2$ to 7.7$)$ & * \\
\hline
\end{tabular}

Values are median (interquartile range)

${ }^{\star} \mathrm{p}<0.05$, TCPC $v$ BDG.

BDG, bidirectional Glenn; EDP, ventricular end diastolic pressure; Qp, pulmonary blood flow; Qs, systemic blood flow; TCPC, total cavopulmonary connection.

after logarithmic transformation of the neurohormonal values. Results are presented as raw data. Statistical significance was inferred at a $p$ value of less than 0.05 .

\section{Results}

CLINICAL CONDITION AND HAEMODYNAMIC DATA These results are given in table 2. All patients were in New York Heart Association (NYHA) functional class I/II and in sinus rhythm. None had gradients across the anastomoses. The three patients with interrupted inferior vena cava had physiologically TCPC and were thus grouped as such.

Systemic arterial pressures, pulmonary artery pressures, central venous pressures, and mixed venous saturations were not significantly different between the TCPC and the BDG groups. Arterial saturation was significantly higher in the TCPC patients $(96 \%(92 \%$ to $99 \%)$ ) than in BDG patients $(90 \%$ (89\% to $92 \%))(\mathrm{p}<0.05)$. Ventricular ejection fraction was classified as normal in 13 patients and mildly reduced in the remaining seven.

NEUROHORMONAL ACTIVITY

Plasma concentrations of angiotensin II, renin, aldosterone, AVP, ANF, and BNP were significantly increased in both patient groups (table 3). Multiple linear regression analysis showed

Table 3 Neurohormonal activity

\begin{tabular}{lllll}
\hline & TCPC $(n=12)$ & BDG $(n=8)$ & TCPC+BDG $(n=20)$ & Control $(n=33)$ \\
\hline Angiotensin II $(\mathrm{pmol} / \mathrm{l})$ & $42(24 \text { to } 109)^{\star}$ & $40(14 \text { to } 97)^{\star}$ & $42(21 \text { to } 106)^{\star}$ & $11(8$ to 15$)$ \\
Renin $(\mu \mathrm{U} / \mathrm{ml})$ & $182(31 \text { to } 267)^{\star}$ & $82(39 \text { to } 202)^{\star}$ & $129(34 \text { to } 256)^{\star}$ & $34(27$ to 41$)$ \\
Aldosterone $(\mathrm{pmol} / \mathrm{l})$ & $306(111 \text { to } 778)^{\star}$ & $111(83$ to 389$)$ & $278(83 \text { to } 500)^{\star}$ & $67(56$ to 117$)$ \\
AVP $(\mathrm{pmol} / \mathrm{l})$ & $1.2(0.5$ to 2.6$)$ & $2.2(1.4 \text { to } 3.0)^{\star}$ & $1.9(0.6 \text { to } 2.6)^{\star}$ & $0.7(0.5$ to 2.5$)$ \\
ANF $(\mathrm{pmol} / \mathrm{l})$ & $13(6 \text { to } 17)^{\star}$ & $20(11 \text { to } 29)^{\star}$ & $15(9 \text { to } 22)^{\star}$ & $6(4$ to 8$)$ \\
BNP $(\mathrm{pmol} / \mathrm{l})$ & $2.2(1.8 \text { to } 3.4)^{\star}$ & $1.6(1.5$ to 2.1$)$ & $2.0(1.5 \text { to } 2.6)^{\star}$ & $1.2(1.0$ to 1.9$)$ \\
\hline
\end{tabular}

Values are median (interquartile range).

${ }^{\star} \mathrm{p}<0.05$ patients $v$ controls. There were no significant differences between TCPC and BDG

ANF, atrial natriuretic factor; AVP, arginine vasopressin; BDG, bidirectional Glenn anastomosis; BNP, brain natriuretic peptide; TCPC, total cavopulmonary connection.

Table 4 Clinical chemistry

\begin{tabular}{llll}
\hline & $T C P C+B D G(n=20)$ & TCPC $(n=12)$ & BDG $(n=8)$ \\
\hline Packed cell volume $(\%)$ & $0.48(0.44 \text { to } 0.55)^{\star}$ & $0.44(0.42 \text { to } 0.47)^{\star}+$ & $0.55(0.52 \text { to } 0.56)^{\star}$ \\
Creatinine $(\mu \mathrm{mol} / \mathrm{l})$ & $64(51 \text { to } 76)^{\star}$ & $66(41$ to 74$)$ & $62(53 \text { to } 85)^{\star}$ \\
Urea $(\mathrm{mmol} / \mathrm{l})$ & $4.7(3.6$ to 5.2$)$ & $4.9(4.4 \text { to } 5.5)^{\star}+$ & $3.6(3.1$ to 4.8$)$ \\
Sodium $(\mathrm{mmol} / \mathrm{l})$ & $141(140$ to 143$)$ & $140(140$ to 141$)$ & $142(141$ to 143$)$ \\
Potassium $(\mathrm{mmol} / \mathrm{l})$ & $4.1(3.9 \text { to } 4.3)^{\star}$ & $4.3(4.1 \text { to } 4.4)^{\star}$ & $4.1(3.7$ to 4.2$)$ \\
Albumin $(\mu \mathrm{mol} / \mathrm{l})$ & $647(617 \text { to } 670)^{\star}$ & $640(617 \text { to } 655)^{\star}$ & $647(617$ to 0.41$)$ \\
\hline
\end{tabular}

Values are median (interquartile range).

${ }^{\star} \mathrm{p}<0.05$ patients $v$ controls; $\mathrm{tp}<0.05$ TCPC $v$ BDG

BDG, bidirectional Glenn anastomosis; TCPC, total cavopulmonary connection. an inverse correlation between follow up interval and plasma levels of angiotensin II $(r=-0.58, \mathrm{p}<0.05)$ and renin $(r=-0.55$, $\mathrm{p}<0.05)$. Patients over the age of 15 years all had neurohormone levels within the normal range. An age correlation was not seen in the controls. There was no correlation between haemodynamic variables and the neurohormone level.

CLINICAL CHEMISTRY

Packed cell volume, creatinine, urea, sodium, potassium, and albumin results are shown in table 4 . The patients had significantly higher packed cell volume, creatinine, potassium, and albumin than the controls $(\mathrm{p}<0.05)$.

\section{Discussion}

Neuroendocrine activation is a key event in the pathogenesis and pathophysiology of heart failure. ${ }^{19}$ In adults, it has been reported not only in patients with clinical heart failure but also in asymptomatic patients with left ventricular systolic dysfunction. ${ }^{20}$ These observations have led to modulations of the neurohormonal systems with angiotensin converting enzyme (ACE) inhibitors ${ }^{10}$ and angiotensin II inhibitors, ${ }^{21}$ with subsequent improvement in symptoms and survival. ${ }^{910} 21$

Activation of the neurohumoral systems has also been documented preoperatively in congenital heart disease. ${ }^{22}{ }^{23}$ Postoperatively, Fontan surgery, in contrast to VSD closure, has been associated with a significant increase in circulating neurohormones, appearing within the first postoperative hour and lasting days. ${ }^{132425}$ After BDG, however, levels were only transiently and moderately elevated..$^{13}$ The aetiology of the early postoperative increase in neurohormones remains unclear, but surgical trauma $^{24}$ and the non-pulsatile heart-lung pump $^{26}$ may influence the levels of hormones and peptides.

Our study extends these immediate postoperative observations and shows that even in asymptomatic patients, vasoconstrictor neuro- 
hormones (angiotensin II, renin, aldosterone, and vasopressin) and vasodilator peptides (ANF, BNP) are significantly raised several years after cavopulmonary operations.

Damaged myocardium has the propensity to remodel. Although this compensatory response may seem beneficial, it induces myocardial hypertrophy and fibrosis, both of which can lead to heart failure. Reductions in cardiac output, reduced flow to vital organs, and altered loading conditions may subsequently lead to activation of the sympathetic nervous system, the renin-angiotensin-aldosterone system, and the arginine-vasopressin system, which seek to increase blood pressure and stimulate cardiac function-all intimately associated with deleterious hypertrophic ${ }^{27}$ and fibrotic processes. ${ }^{28} \mathrm{ANF}$ is produced and released from atrial myocytes in response to increased filling pressures. The raised ANF levels suppress the renin-angiotensinaldosterone system and thus counter-regulate the proliferative activity associated with activation of the system..$^{20} \mathrm{BNP}$ is mainly produced in the systolic dysfunctional ventricles ${ }^{11}$ and is considered a cardiac hormone against ventricular overload. ${ }^{29}$

The reason for the neurohormonal activation observed late after cavopulmonary connection remains elusive. Our current understanding of these regulatory and compensatory systems is almost exclusively based on studies performed in animals and humans with a biventricular circulation, and may not fully apply to the unique Fontan circulation. Several of these stimuli are, however, also operative after cavopulmonary connection. Thus the univentricular heart is preoperatively characterised by volume overload, and both the TCPC and the BDG procedures decrease the volume burden of the functional single ventricle. ${ }^{30}$ This load reduction requires adaptive mechanisms including ventricular remodelling to assure haemodynamic homoeostasis.

The cavopulmonary connection operates at higher filling pressures which promote natriuresis through increased ANF release, reduce systemic and pulmonary vascular resistance, increase venous capacitance, and decrease cardiac filling. ${ }^{31}$ ANF infusions have indeed been shown to improve haemodynamics within the first postoperative hour after an atriopulmonary connection. ${ }^{33}$ The increased BNP levels may not only be directly related to the hypertrophy generally seen postoperatively but may also play a complementary role to ANF in controlling pulmonary vascular responses. ${ }^{31}$

Finally, the lack of normal pulmonary arterial pulsation and the raised renal venous pressure seen following the cavopulmonary connection may influence the functional state of pulmonary mechanoreceptors, reduce the renal perfusion pressure, and thus activate the renin-angiotensin-aldosterone axis.

In this study, we were unable to identify any correlation between neurohormonal levels and haemodynamic variables. However, the small size of the study population and the narrow range of haemodynamic values provided limited statistical power. Positive correlations between central venous pressure, pulmonary blood flow, and ANF have been reported in children with various congenital disease ${ }^{23}$ and in adults with atrial septal defects. ${ }^{22}$ Furthermore it has been proposed that neurohormone levels are correlated with the extent of ventricular dysfunction, ${ }^{11}$ being increased up to 30 -fold in patients in NYHA functional class IV. ${ }^{34}$ Our patients only showed a doubling of $\mathrm{ANF}$ and BNP levels, corresponding to slightly increased central venous pressures, a moderately reduced ejection fraction, and the fact that all the patients being classified as NYHA class I/II.

Interestingly, neurohormonal levels were raised only in the younger age group, but were normal in all five patients over the age of 15 years. The reason for this is unclear, but it agrees with previous observations in adult patients undergoing Fontan surgery more than one year previously. ${ }^{8}$ Although a negative correlation between age and neurohormones has been described in children under three years of age, ${ }^{35}$ no age correlation was observed in controls aged six years or more. It is possible that neurohormone levels gradually adapt to the cavopulmonary physiology, as indicated by the reduced exercise induced ANF release seen several years after atriopulmonary surgery. ${ }^{36}$ Although less likely in this cohort, it has been proposed that the relative contributions of the circulating (plasma) and tissue renin-angiotensin-aldosterone concentrations vary during the natural history of heart failure, with increased levels during phases of acute heart failure and decompensation, and normal levels during compensated phases. ${ }^{37}$

The efficacy of ACE inhibitors in the cavopulmonary circulation is much debated. Although ACE inhibitors improved exercise capacity in children with congestive cardiomyopathy, ${ }^{38}$ enalapril did not increase exercise tolerance in 18 well compensated patients four to 19 years after Fontan procedure. ${ }^{39}$ Whether ACE inhibitors are beneficial in the early or mid-term postoperative phase when neurohormones are raised needs to be evaluated prospectively, and preferably with hard end points rather than surrogate markers such as neurohormone levels. Currently, we are left with the question of whether the neurohormonal activation is a beneficial and temporary effect during haemodynamic accommodation to the cavopulmonary circulation or an early sign of ventricular dysfunction.

Several limitations to this study have to be considered. Our primary aim was to elucidate neurohormonal status late after the cavopulmonary operation, and information on preoperative neurohormone levels was omitted. Similarly, inclusion of a control group comprising children with unoperated and operated simple cardiac lesions would have added information on the status of the neurohormone systems in non-cavopulmonary patients. The cross sectional study design excluded the possibility of describing temporal changes and haemodynamic relations of neurohormones in the individual cavopulmonary operated patient. In the calculation of flow, the standard 
Fick principle was employed. This clearly introduces some inaccuracies in optimal flow assessment.

Nevertheless, raised neurohormonal levels were observed several years after successful cavopulmonary operations but levels seemed to normalise over time. This pattern suggests that neurohormonal activation is primarily related to the altered postoperative physiology and that adaptation takes place over time. Further studies are needed to extend our findings with a view to studying the potential pharmacological modulation of these important regulator mechanisms.

We acknowledge laboratory technicians Bente Mortensen, Marianne Lyngbak, Lisbeth Mikkelsen, Eva Sparevath and Marianne Lyngbak, Lisbeth Mikkelsen, Eva Sparevath and
Bente Jakobsen for their expert help. The Danish Medical Bente Jakobsen for their expert help. The Danish Medical Hede Nielsen Family Foundation provided financial support.

1 Harrison DA, Liu P, Walters JE, et al. Cardiopulmonary function in adult patients late after Fontan repair. $\mathcal{F} \mathrm{Am} \mathrm{Coll}$ function in adult patients late

2 Rosenthal M, Bush A, Deanfield J, et al. Comparison of cardiopulmonary adaptation during exercise in children after the atriopulmonary and total cavopulmonary connection Fontan procedures. Circulation 1995;91:372-8.

3 Reybrouck T, Rogers R, Weymans M, et al. Serial cardiorespiratory exercise testing in patients with congenital heart disease. Eur f Pediatr 1995;154:801-6.

4 Norgård G, Gatzoulis MA. Value of exercise testing in the assessment of the Fontan operation. Cardiol Young 1996;6: $106-8$.

5 Mertens L, Rogers R, Reybrouck T, et al. Cardiopulmonary response to exercise after the Fontan operation: cross-sectional and longitudinal evaluation. Cardiol Young 1996;6:136-42.

6 Troutman WB, Barstow TJ, Galindo AJ, et al. Abnormal dynamic cardiorespiratory responses to exercise in pediat-
ric patients after Fontan procedure. $\mathcal{F ~} \mathrm{Am}$ Coll Cardiol ric patients after

7 Kiana A, Shakibi JG. Fontan physiology. Circulation 1995;92:3149-50.

8 Kelly JR, Mack GW, Fhey JT. Diminished venous vascular capacitance in patient with univentricular hearts after the Fontan operation. Am f Cardiol 1995;76:158-63.

9 The CONSENSUS trial study group. Effects of enalapril on mortality in severe congestive heart failure: results of the cooperative North Scandinavian Enalapril Survival Study (CONSENSUS). N Engl f Med 1987; 316:1429-35.

10 SOLVD Investigators. Effect of enalapril on mortality and the development of heart failure in asymptomatic patients
with reduced left ventricular ejection fractions. $N$ Engl 7 Med 1992;327:685-91.

11 McDonagh TA, Robb SD, Murdoch DR, et al. Biochemical detection of left-ventricular systolic dysfunction. Lancet 1998;351:9-13.

12 Vantrimpont P, Rouleau JL, Ciampi A, et al. (for the SAVE investigators). Two-year time course and significance of neurohumoral activation in the Survival and Ventricular Enlargement (SAVE) Study. Eur Heart f 1998;19:52-63.

13 Mainwaring RD, Lamberti JJ, Moore JW, et al. Comparison of the hormonal response after bidirectional Glenn and of the hormonal response after bidirectional Glen
Fontan procedure. Ann Thorac Surg 1994;57:59-64.

14 Kappelgaard AM, Damkjaer Nielsen M, Giese J. Measurement of angiotensin II in human plasma: technical modification and practical experience. Clin Chim Acta 1976;67 299-306

15 Rask-Madsen J, Bruusgaard A, Munck O, et al. The significance of bile acids and aldosterone for the electrical hyperpolarization of human rectum in obese patients treated with intestinal by-pass operation. Scand f Gastroenterol 1974;9:417-26.

16 Pedersen EB, Danielsen H, Spencer ES. Effect of indapamide on renal plasma flow, glomerular filtration rate and arginine vasopressin in plasma in essential hypertension. Eur f Clin Pharmacol 1984;26:543-47.

17 Thomassen A, Bagger JP, Nielsen TT, et al. Atrial natriuretic peptide during pacing in controls and patients with coronary artery disease. Int $\mathcal{F}$ Cardiol 1987;17:267-76.

18 Jensen KT, Carstens J, Ivarsen P, et al. A new, fast and reliable radioimmuno-assay of brain natriuretic peptide in human plasma. Reference values in healthy subjects and in patients with different diseases. Scand $\mathcal{F}$ Clin Lab Invest 1997;57:529-40.

19 Komajda M, Isnard R, Lechat P. The role of the neurohormonal system in heart failure. Heart 1998;79(suppl 2):S17-23.

20 Francis GS, McDonald KM, Cohn JN. Neurohumoral activation in preclinical heart failure. Remodeling and the potential for intervention. Circulation 1993;87(suppl IV): IV-90-6.

21 Pitt B, Segal R, Martinez FA, et al (on behalf of ELITE study investigators). Randomised trial of losartan versus captopril in patients over 65 with heart failure (Evaluation of Losartan in the Elderly Study, ELITE). Lancet 1997;349:747-52.

22 Nagaya $N$, Nishikimi $T$, Uematsu $M$, et al. Secretion patterns of brain natriuretic peptide and atrial natriuretic peptide in patients with or without pulmonary hypertension complicating atrial septal defect. Am Heart 7 1998; 136:297-301.

23 Kindelan AA, Navaro JLP, de la Rosa, et al. Relationship between hemodynamic changes and blood hormone concentrations after cardiac surgery in children with congenital heart disease. Crit Care Med 1994;22:1754-61.

24 Stewart JM, Seligman KP, Zeballos G, et al. Elevated natriuretic peptide after the Fontan procedure. Circulation 1987;76(suppl III):III-77-82.

25 Stewart JM, Gewitz MH, Clarke BJ, et al. The role of vasopressin and atrial natriuretic factor in postoperative fluid retention after the Fontan procedure. 7 Thorac Cardiovasc Surg 1991;102:821-9.

26 Nagaoka H, Innami R, Arai H. Effects of pulsatile cardiopulmonary bypass on the renin-angiotensinaldosterone system following open heart surgery. fpn f Surg 1988;18:390-6.

27 Morgan HE, Baker KM. Cardiac hypertrophy; mechanical, neural, and endocrine dependence. Circulation 1991;83: $14-25$.

28 Kato H, Suzuki H, Tajima S, et al. Angiotensin II stimulates collagen synthesis in the cultured vascular smooth muscle cells. F Hypertens 1991;9:17-22.

29 Maeda K, Tsutamoto T, Wada A, et al. Plasma brain natriuretic peptide as a biochemical marker of high left ventricular end-diastolic pressure in patients with symptomatic left ventricular dysfunction. Am Heart 7 1998;135:825-32.

30 Geggel RL. Update on the modified Fontan procedure. Curr Opin Cardiol 1997;12:51-62.

31 Hill NS, Klinger JR, Warburton RR, et al. Brain natriuretic peptide: possible role in the modulation of hypoxic pulmonary hypertension. Am F Physiol 1994;266:L 308-15.

32 Levin ER, Gardner DG, Samson WK. Natriuretic peptides. N Engl f Med 1998;339:321-8.

33 Hiramatsu T, Imai Y, Takanashi Y, et al. Hemodynamic effects of human atrial natriuretic peptide after modified Fontan procedure. Ann Thorac Surg 1998;65:761-4.

34 Burnett JC, Kao PC, Hu DC, et al. Atrial natriuretic peptide elevation in congestive heart failure in the human. Science 1986;231:1145-7.

35 Fiselier TJW, Lijnen P, Mionnens L, et al. Levels of renin, angiotensin I and II, angiotensin-converting enzyme and aldosterone in infancy and childhood. Eur $\mathcal{f}$ Pediatr 1983;141:3-7.

36 Perrault H, Miro J, Davignon A, et al. Decreased plasma atriopeptin response to volume-overloading maneuvers and atriopeptin response to volume-overloading maneuvers and Cardiol 1992;69:1325-8.

37 Hirsch AT, Dzau VJ. Tissue renin angiotensin system in the pathophysiology of heart failure. In: Brachmann J, Dietz R, Kubler W, eds. Heart failure and arrhythmias. Heidelberg: Springer-Verlag, 1990:33-42.

38 Bengur AR, Beekman RH, Rocchini AP, et al. Acute hemodynamic effects of captopril in children with a congestive or restrictive cardiomyopathy. Circulation 1991;83:523-7.

39 Kouatli AA, Garcia JA, Zeller TM, et al. Enalapril does not enhance exercise capacity in patients after Fontan procedure. Circulation 1997;96:1507-12. 